\title{
RECENT DEBRIS-FLOW AND FLASH-FLOOD HISTORY OF NORTHEASTERN Yellowstone National PARK
}

\author{
JOSHUA D. LANDIS $\downarrow$ GRANT A. MEYER \\ MIDDLEBURY COLLEGE $\downarrow$ MIDDLEBURY $\downarrow \mathrm{vT}$
}

\section{$\downarrow \quad$ INTRODUCTION}

An understanding of the ecological health of stream systems and riparian areas in Yellowstone National Park (YNP) requires knowledge of their response to climatic and hydrological influences; intrinsic factors such as relief and geological materials are important influences as well (e.g., O'Hara and Meyer 1995). Recent studies of southwestern (Ely et al. 1993) and midwestern U.S. rivers (Knox 1993) have shown that relatively minor climatic changes in the late Holocene are associated with large fluctuations in flood magnitude and frequency. In small, steep drainage basins of northeastern YNP (Figure 1), Meyer et al. (1992, 1995) associated increased fire-related debris-flow activity with decadal to millennial-scale cycles of drought over the Holocene. Observations of modern events indicate that debris-flow and flash floods are also produced in the absence of fire in this rugged mountainous region, primarily by intense summer thunderstorm precipitation. Although a correlation between drought severity and fire magnitude in Yellowstone is clear (Balling et al. 1992a, 1992b), the relationship hypothesized by Meyer et al. (1992, 1995) between warm, drought-prone climatic episodes and debris-flow activity in this region requires further investigation. Therefore, we use relatively high-resolution lichenometric and treering dating methods to construct a 250-year history of major hydrologic events in small, steep tributary basins of Soda Butte Creek in northeastern

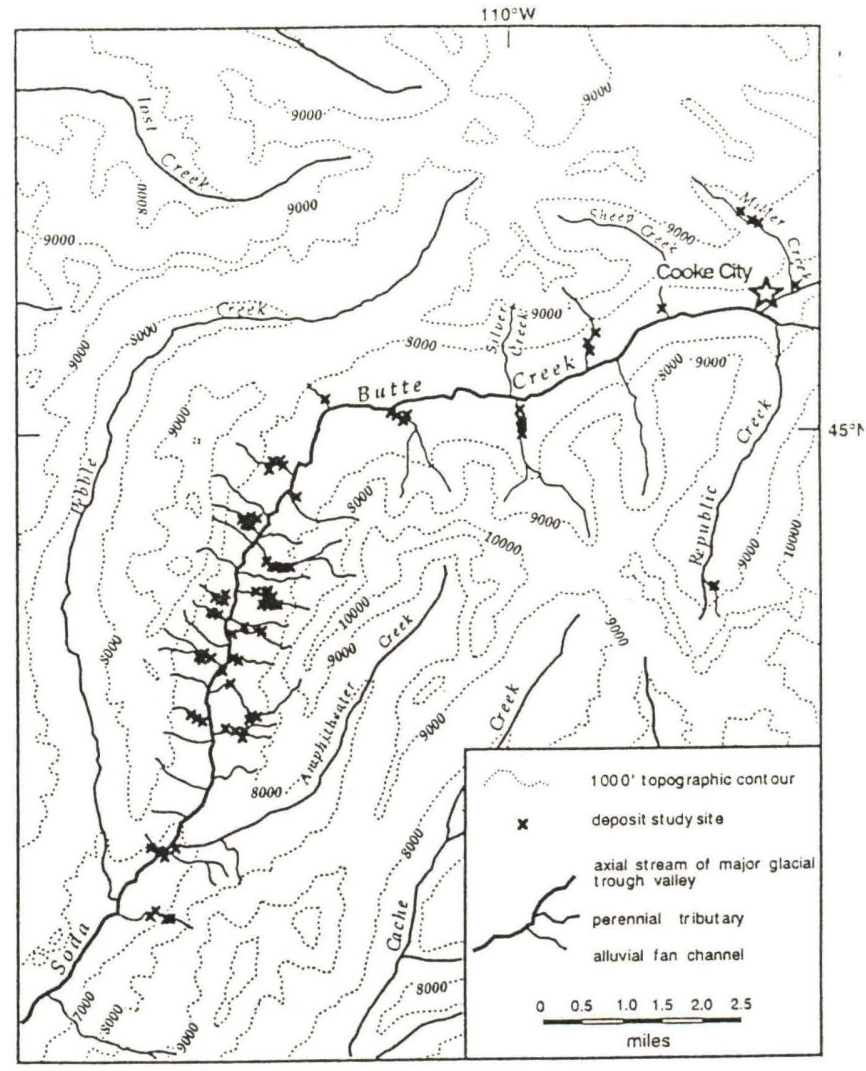

Figure 1. Map of the study area in northeastern YNP showing deposit locations on alluvial fans in the Soda Butte Creek valley.

Yellowstone. This period spans the transition from the generally cooler global climate of the Little Ice Age to the present (e.g., Grove 1988). Although 
the Little Ice Age was not uniformly cold in either a spatial or temporal sense (Jones and Bradley 1995), and YNP climate is not well known in the earlier part of this interval, trends toward increasing summer temperatures and decreasing winter precipitation in YNP over the last $\sim 100 \mathrm{yr}$ are consistent with this transition (Balling et al. 1992a).

\section{$\downarrow \quad$ STUDY AREA}

The Soda Butte Creek valley is a glacial trough cut in Eocene andesitic volcaniclastic rocks underlain by paleozoic carbonate rocks. The exposed, friable volcaniiclastic bedrock on the upper valley walls is capable of generating abundant, rapid runoff for producing debris flows and flash floods, and weathers rapidly to produce abundant fine sediments conducive to debris flows (e.g., Pierson and Costa 1987). Vegetation covering middle and lower basin slopes consists mostly of mixedconiferous forest dominated by lodgepole pine (Pinus contorta), with lesser Douglas fir (Pseudotsuga menziesii) and Engelmann spruce (Picea engelmannii). Devegetation by large standreplacing forest fires may have promoted some debris flows in the earlier part of the study period, but little evidence exists for major fires in the last $\sim 120$ years in this area (Barrett 1994). Thin colluvium, an absence of headscarps on slopes, and deeply incised channels in source basins suggest that debris flows occur primarily from bulking of sediment in erosive flows (Meyer et al. 1995) rather than en masse regolith failures as is often observed in other areas (e.g., Ellen and Fleming 1987). Flash floods result in basins where available sediment is insufficient to produce a transition from streamflow to debris flow, but similarly require intense precipitation.

Regolith failures do initiate debris flows in the study area, e.g., on Silver Creek near the Northeast Entrance of YNP, where till in a lateral moraine in the upper basin failed following melting of a heavy snowpack and moderate rainfall on June 17, 1996. Thick remnant glacial deposits are uncommon on the upper slopes of northeastern YNP (Pierce 1974), however, and intense convectivestorm precipitation on steep exposed bedrock is likely responsible for most debris-flow activity. Antecedent precipitation and wet climatic conditions are not prerequisites for debris flows. For example, debris flows and flash floods were generated in many small tributaries of middle Soda Butte Creek by a single intense thunderstorm in late June 1988, during the driest summer on record in YNP (Balling et al. 1992b).

Most alluvial fans along Soda Butte Creek are fed by basins of $<4 \mathrm{~km}^{2}$ with high relief and drainage density, and have radial lengths of 0.3-0.9 $\mathrm{km}$ and slopes of $3^{\circ}-15^{\circ}$. Incised channels are common on these fans (O'Hara and Meyer 1995). Bouldery debris-flow deposits are common near fanheads; they are also found on medial to distal fans bordering incised channels and at intersection points where channels emerge on the fan surface. Boulder bars from flash floods lie in channels or accompany sheetflood gravel deposits below intersection points.

Yellowstone precipitation is characterized by two regimes: (1) a strong winter precipitation maximum that is dominant in high elevations of northeastern YNP, and (2) a summer precipitation maximum with more localized intense thunderstorms in the lower and drier valleys of the northern park (Despain 1987; Whitlock and Bartlein 1993). The study area in northeastern YNP is thus characterized by both general, widespread snowfall in the coolseason maximum and localized intense rain in the summer (Trewartha 1981). Dry summers in the mountains of northeastern YNP result when the eastern subtropical Pacific high-pressure' system is displaced north and east, with anticyclonic dry air flow dominating local weather patterns (Whitlock and Bartlein 1993). This pattern allows intense insolation as well, so dry summers are typically very warm (Douglas and Stockton 1975). Nonetheless, YNP is susceptible to intrusions of summer moisture through the Columbia River and Snake River Plains (Whitlock and Bartlein 1993).

\section{$\downarrow \quad$ METHODS \\ DEBRIS-FLOW AND FLASH-FLOOD DEPOSITS}

Debris-flow and flood deposits were identified by characteristic morphologic and sedimentologic properties (e.g., Costa 1988). Debris-flow deposits in the study area typically feature steep, bouldery, matrix-poor lobe fronts and levees. These substrates are particularly suitable for lichen colonization. Debris-flow deposits and 
bouldery flash-flood facies are not always easily differentiated, but the latter show greater sorting and imbrication and contain no muddy matrix. Both types of deposits may be produced by a single thunderstorm-runoff event. The sampled deposits are dominated by debris-flow facies; less than $10 \%$ of 156 deposits were identified as flood deposits. Therefore, we consider all deposits as a single group in examining the distribution of events over time. The magnitude of the event that emplaced a given deposit was classified as large, intermediate, or minor based on deposit area and the size of the largest clasts.

\section{LICHENOMETRIC DATING}

Lichens grow at a definable rate on large clasts after emplacement of a deposit, and functions describing growth rate can be defined where independent ages can be obtained on the time of deposition (Innes 1985a). Lichen specimens from four sites in the study area were identified as Rhizocarpon riparium, a species virtually identical to the more familiar $R$. geographicum commonly used in lichenometric studies; both are classified in the same Section, and may not be distinct species (S. Eversman, personal communication 1996). Therefore, following Innes (1983a), we refer to the sampled lichens as the "aggregate species" Rhizocarpon Section Rhizocarpon.

Flood bars of known age along upper Soda Butte Creek, previously dated by historical records and dendrochronological study of large, even-aged conifer stands (Bingham and Meyer 1994; Simpson and Meyer 1995), were searched exhaustively for all of the larger lichens present. The greatest diameter of each single, ovoid thallus was measured with dial calipers to the nearest $0.25 \mathrm{~mm}$. We then calculated the average diameter of the largest five thalli $\left(\bar{d}_{5}\right)$ as an index of substrate age. These flood bars served as primary (hereafter referred to as "group A") calibration sites; additional calibration sites ("group $\mathrm{B}^{n}$ sites) were established by tree-ring dating of debris-flow deposits within the study area (e.g., Hupp et al. 1987).

Two potential sources of error arise in our application of lichenometry, however: Anomalously large lichens, formed by fusion of adjacent individuals (Jahns 1973) or preservation of a thallus on a transported clast (Innes 1983b), may yield erroneously old age estimates. We rejected lichens as anomalously large where the ratio of $\bar{d}_{5}$ to the single largest thallus measurement was more than 2 standard deviations below the mean of all such ratios (e.g., Innes 1983b). (2) The probability of finding the largest possible lichen is related to the area searched (Innes 1984). This problem required consideration of the size distribution in lichen populations. Lichen thalli are subject to microclimatic control of growth rate, and the chance of finding the largest lichen (that which has grown under optimal conditions) increases with the size of the area searched (Innes 1985b). The size of the largest thallus should also be related to the number of thalli present at a site; i.e., on two deposits of the same age, the larger deposit with the greater total number of thalli will also have a larger maximum thallus size.

To define the differences in lichen $\bar{d}_{5}$ measurements that result from sampling different deposit sizes, we employed a statistical resampling method. Using nine large deposits, we randomly drew subsamples of $5,10,20,30$, and 40 measurements (where possible) from each large sample of measured diameters $(n=34$ to 100$)$. We then averaged the largest five measurements in each subsample (Figure 2). A total of 100 iterations were performed for each subsample size, and results were averaged. A logarithmically increasing function was found to best fit the relationship between sample size and $\bar{d}_{5}$ measurements. Samples were corrected to the median sample size $(n=15)$ to minimize data alteration, using a correction ratio derived from the $\log$ function:

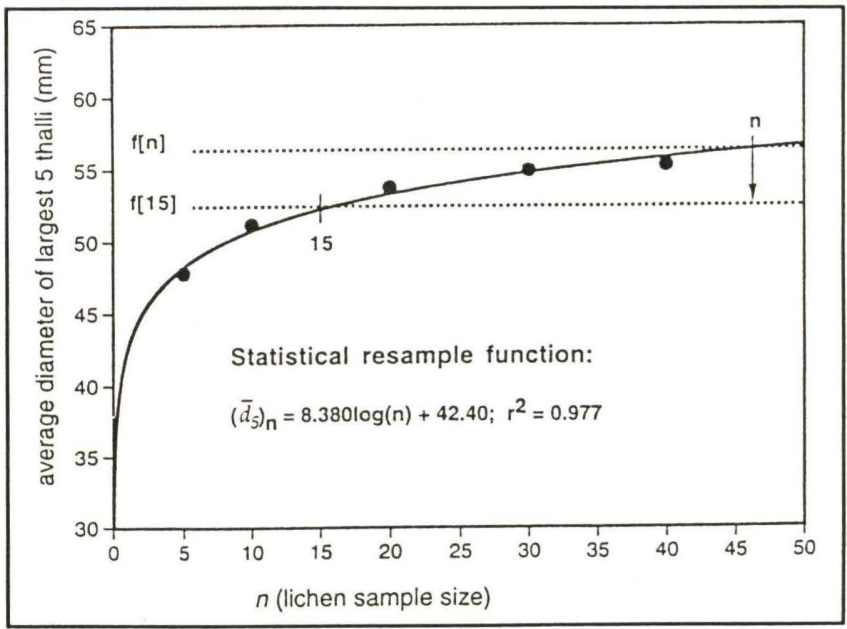

Figure 2. Statistical resampling results from a single lichen measurement site. A logarithmic function $f$ defines the predicted increase in $\bar{d}_{5}$ values with increasing sample size; this functin was used to calculate site-specific correction ratios $f[15] / f[\mathrm{n}]$. 
correction ratio $\left.\left.=f{ }^{\bar{d}_{5}}\right]_{15 / f[} \bar{d}_{5}\right]_{\mathrm{n}}$

Correction ratios for $\mathrm{n}=5,10,15$, etc., derived from each of the nine sites used for resampling were plotted as a function of $\mathbf{n}$ and fit with a logarithmically decreasing curve $\left(r^{2}=0.944\right)$ (Figure 3). From this curve, a $\bar{d}_{5}$ correction function was derived:

$\mathrm{C}=\mathrm{U} *(1.232-0.196 * \log n)$

where $\mathrm{C}$ is the corrected $\bar{d}_{5}$ measure and $\mathrm{U}$ is the uncorrected $\bar{d}_{5}$ measure. This function thus estimates the dependence of $\bar{d}_{5}$ on sample size, and was applied to all samples to correct for sample size effects. The function also indicates that the difference between $\bar{d}_{5}$ values increases rapidly as sample size declines below about eight, suggesting that sample sizes smaller than this may result in large errors in age estimates. Samples with fewer than eight lichen measurements were therefore discarded.

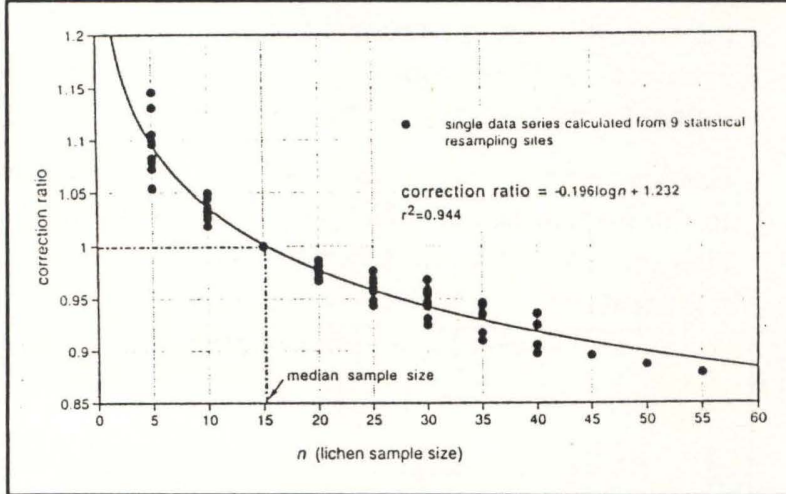

Figure 3. The correction function, a decreasing logarithmic curve that integrates the results from 9 statistical resampling sites and predicts the best-fit correction ratio $f[15] / f[\mathrm{n}]$ for any lichen sample size $\mathrm{n}$. This correction function was used to modify $d_{5}$ measurements of all deposits to account for variations in lichen sample size.

\section{RESULTS}

After correcting for anomalously large lichen and sample size, growth of Section Rhizocarpon lichens in northeastern YNP was found to be nearly linear $\left(\mathrm{r}^{2}=0.987 ; \mathrm{n}=12\right)$ from 30 to at least 200 years ago, and is described by the regression equation:

$$
\bar{d}_{5}=0.172 \mathrm{t}+4.177
$$

where $\bar{d}_{5}$ is given in millimeters and $\mathrm{t}$ is age in years before 1996. A positive $y$-intercept indicates a rapid initial growth phase prior to 30 years ago that is typical of lichens (Hale 1973). Measurements from a tree-ring dated $\sim 1969$ deposit and the conspicuous absence of thalli on 1988 deposits support this conclusion. These observations also indicate a colonization period of 10-20 years for Section Rhizocarpon lichens in northeastern YNP.

The growth curve regression formed the basis for a linear calibration curve for estimating the age of deposits from lichen measurements (Figure 4):

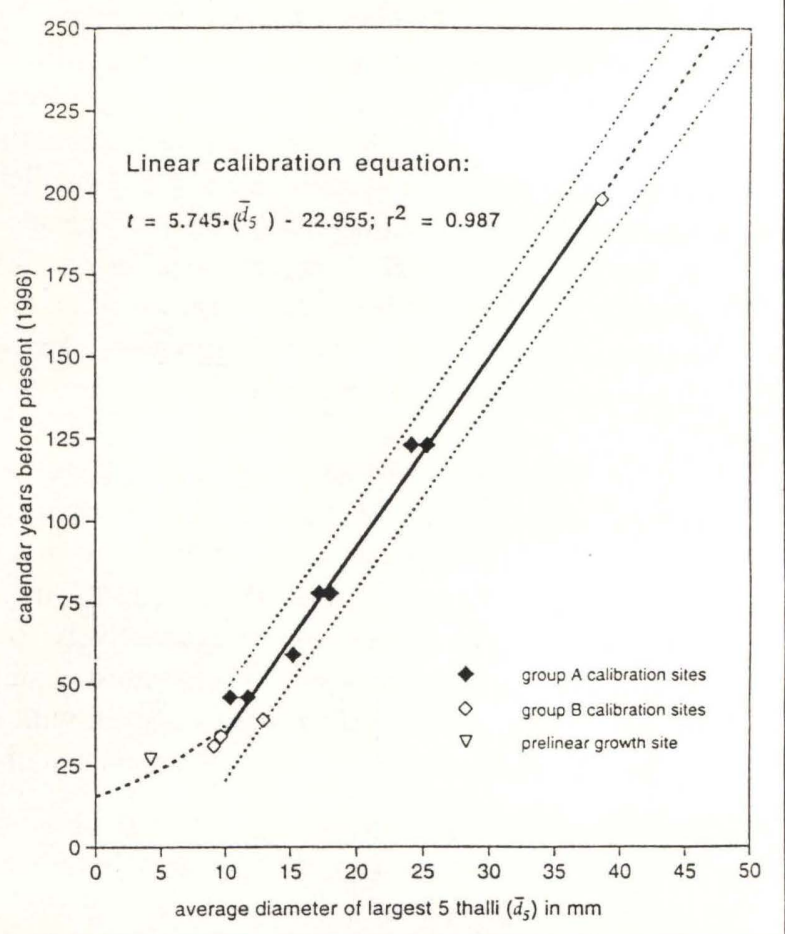

Figure 4. Rhizocarpon Section Rhizocarpon lichen linear calibration curve, which predicts deposit age of from the $d$ value of the lichen sample corrected for sample size. Dotted gray lines are $95 \%$ confidence limits, Data suggest a colonization period of 10-20 years, followed by an initial rapid growth phase (dashed curve) and a subsequent linear growth phase. See text for a description of calibration site categories.

$\mathrm{t}=5.745 *\left(\bar{d}_{5}\right)-22.955$ 
with $\mathrm{r}^{2}=0.987$ and $\mathrm{n}=12$. The regression has $95 \%$ confidence limits of about \pm 14 years. This calibration function was applied to all lichen sample data. The oldest deposits sampled, however, were estimated to be over 600 years old, well beyond the oldest calibration date of $\sim 200 \mathrm{yr}$. Extension of the function this far prior to the calibration period is unwarranted, because long-term growth rates may decline with time in a curvilinear or sigmoidal fashion (Hale 1973; Innes 1985a). Therefore, only dates for those events within the last 250 years are reported.

Because an event often produces multiple deposit lobes on a fan, deposits dated to within about 14 years of one another on a given fan were possibly emplaced in the same event. Frequently, we found events to have been dated within 1-4 years of one another; events 5-14 years of one another were uncommon. Where these deposits were adjacent or on the same fan, their ages were averaged and considered as a single event. Ages of adjacent deposits that showed clear inset morphostratigraphic relationships consistent with their ages were left unmodified. In a single instance, deposit morphostratigraphy contradicted the age relationship indicated by lichenometric dates; the ages of these deposits were averaged.

\section{DEBRIS-FLOW AND FLASH-FLOOD HISTORY}

A histogram showing the frequency of debris-flow and flash-flood events from 1750 to $\sim 1930$ shows an apparent trend of increasing activity toward the present (Figure 5). This trend is most likely due to erosion and burial of older deposits over time; only a relatively few large deposits older than about 1800 remain preserved. Punctuating the overall trend are several periods of increased activity, indicated by a relative peak in the number of events as well as a larger magnitude of events. Intervals of greatest debris-flow and flashflood activity are 1810-1820, 1860-1870, and 19101930, with lesser increases from 1840-1850 and 1890-1900. The decline in frequency and magnitude of events from 1930 through 1970 is likely real, as deposits of this young age should be well preserved.

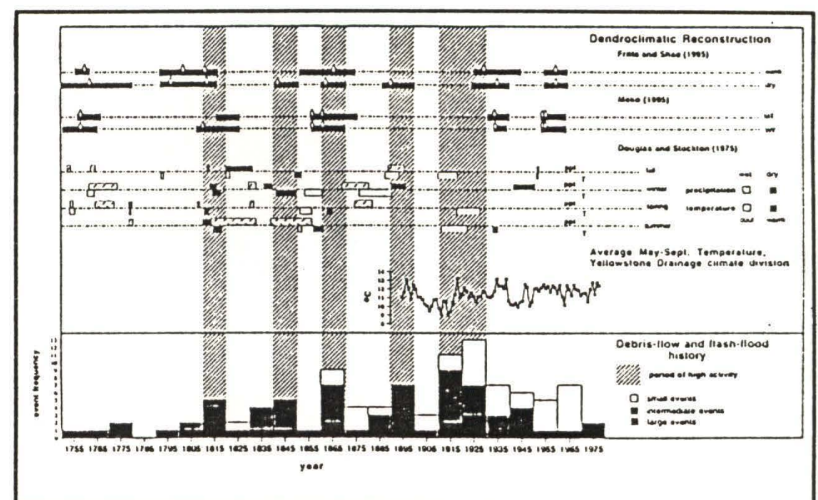

Figure 5. Histogram of debris-flow and flash-flood events compared to local and regional climate records; ten-year periods of greated activity are shaded. Climate records are from Fritts and Shao (1995), a dendroclimatic reconstruction of warm and dry deviations for the northern High Plains, with white diamonds marking years of peak warmth and drought; Meko (1995), a dendroclimatic reconstruction of drought episodes for eastern MT and WY, with white diamonds indicating years of widespread Great Plains drought; Douglas and Stockton (1975), a dendroclimatic reconstruction for the YNP area, with greatest departures from the instrumental record mean plotted for each season; and the instrumental record of average MaySeptember temperatures for the Yellowstone Drainage climate division.

\section{$\downarrow \quad$ DISCUSSION}

In regions where debris flows are initiated by saturation-induced en masse failures of regolith, a general correlation between wetter climatic conditions and debris flow frequency is expected. However, if debris flows and flash floods in northeastern YNP are initiated primarily by intense thunderstorm precipitation, and only locally by saturation-induced failures, then understanding the relationship of debris-flow frequency to climatic changes is more difficult. A single intense rainfall event in an otherwise dry period may produce major debris flow activity. Unfortunately, detailed local precipitation records necessary to reveal such events are available only for the period after 1948 as daily totals at the Cooke City and Northeast Entrance stations. Because even these data overlap only a brief part of the debris-flow record that shows little variability, we are limited to general comparisons with average climatic conditions in regional instrumental records from 1895 to present (e.g., Balling et al. 1992a, 1992b), and dendroclimatic reconstructions for earlier periods (Douglas and Stockton 1975; Fritts and Shao 1995; Meko 1995). 
Instrumental climate data from the Yellowstone Drainage climate division, which covers the northern $\sim 3 / 4$ of Yellowstone and a smaller area on the northeast, include mean monthly temperature and total monthly precipitation for 1895 to the present. To investigate the effect of warmth on debris-flow generation through convective storms, temperatures for the main thunderstorm season (May-September) were averaged and compared to the debris-flow record (Figure 5). Unusually warm late spring-summer weather in 1897, 1900, and 1919 corresponds with general peaks in debris-flow activity; however, similar warm seasons in 1937 and 1940 saw no unusual debris-flow activity, perhaps because the extended regional drought of the 1930 s depleted land-based moisture sources for convective-storm precipitation. June of 1988 was the warmest June on record, and produced a debris-flow and flash-flood event of intermediate scale, but the warmest May-September season on record (in 1994) did not produce any observed events. The pronounced cooling trend in May-September weather of 1900-1910 also corresponds with a relative minimum in debris-flow activity, but large debris flows dated to within the 1910-1920 interval may have occurred during the notably cool and wet period of 1905-1917.

The dendroclimatic record of Douglas and Stockton (1975) for the Yellowstone area shows that intervals of major debris-flow activity between $1810-1820$ and $1860-1870$ coincide with some of the warmest spring-summer conditions between 1750 and 1974 (Figure 5). In agreement with instrumental data, however, this tree-ring record indicates general cool conditions and no precipitation anomalies for the period of 1910-1930, when debris-flow activity is high; the very warm summer of 1919 is the only exception. It should be noted that a major flood occurred on the mainstem of Soda Butte Creek in June 1918 (an unusually warm month) due to prolonged rain on melting snow (Bingham and Meyer 1994), and debris flow activity within the 1910-1930 period may have occurred in association with that event. There is no clear depositional or geomorphic evidence, however, linking debris flow or flood deposits on small tributaries to the 1918 flood bars which are prominent on the lower mainstem of Soda Butte Creek. Debris-flow and flash-flood activity was also relatively low in the unusually wet winter and spring weather of 1872-1890, suggesting that saturation from snowmelt or spring rains is not an important antecedent condition for debris-flow initiation in northeastern YNP; however, a major flood occurred on mainstem Soda Butte Creek during the early part of this interval (Simpson and Meyer 1995).

Increased debris-flow and flash-flood activity in northeastern YNP in the periods 18101820 and 1860-1870 (and perhaps $\sim 1750-1770$ and 1925-1935) occurred during periods of drought on a broad regional scale, as indicated by dendroclimatic records from the northern High Plains (Fritts and Shao 1995; Meko 1995) (Figure 5). The 1950s drought, although prominent in YNP instrumental records and regional tree-ring data, does not correspond to a pulse of debris-flow activity.

Changes in the overall frequency and magnitude of debris flows over the period of record are difficult to interpret, given the trend of increasing preservation that is expectable (Schumm 1991). Large-magnitude debris flows appear to be more common from 1800 to 1870 than in subsequent years. Numerous anomalous periods in Douglas and Stockton's (1975) YNP dendroclimatic reconstructions over this period suggest a highly variable climate. It is also possible that greater sediment production and storage in basins prior to this time during the colder climate of the Little Ice Age led to more available sediment for generation of large debris flows. Some large debris flows may also have been related to forest fires within this period. The reduced frequency and magnitude of debris flows from 1940-1970 is unlikely to be an artifact of sampling bias or preservation, and may relate to the generally cool to moderate late springsummer temperatures of that period.

\section{$\downarrow \quad$ CONCLUSIONS}

Overall, there appears to be some correspondence between warm, drought-prone periods and heightened debris-flow and flash-flood activity over the last 250 years in northeastern YNP, but details of the climate-hydrological process relationship cannot be resolved by these data. Intense summer thunderstorms are clearly important in debris-flow generation, but the time resolution of the debris-flow record is coarse relative to the short duration of these storms. The relationship between convective-storm intensity and general climatic 
conditions in the YNP region also needs further investigation. Also, large debris flows in at least some basins are associated with saturated regolith or high pore pressure conditions promoted by a generally wet climate, mostly where till, landslide deposits, or weak, clay-rich bedrock (e.g., Cambrian shales) are present on steep slopes. Church and Miles (1987) encountered similar uncertainties in their study of meteorological antecedents to debris flows in southwestern British Columbia. Nonetheless, it seems reasonable to suggest that if current trends toward warmer summer temperatures and increased drought severity continue in the YNP area (Balling et al. 1992a, 1992b), debris-flow and flash-flood activity will likely increase as well, in part due to increased magnitude and intensity of forest fires. An additional hypothesis is that major debris-flow events may be most likely to occur when very warm late spring-summer weather follows generally wet conditions, providing both abundant land-based moisture and thermal energy for convective storms in this interior continental region.

\section{LITERATURE CITED}

Balling, R.C., Jr., G.A. Meyer, and S.G. Wells. 1992a. Climate change in Yellowstone National Park: Is the drought-related risk of wildfires increasing? Climate Change 22:34-35.

Balling, R.C., Jr., G.A. Meyer, and S.G. Wells. 1992b. Relation of surface climate and burned area in Yellowstone National Park. Agricultural and Forest Meteorology 60:285-293.

Barrett, S.W. 1994. Fire regimes on andesitic mountain terrain in northeastern Yellowstone National Park, Wyoming. International Journal of Wildland Fire 4:65-76.

Bingham, M.K., and G.A. Meyer. 1994. Flood history since 1800 in relation to late Holocene climate change and stream incision, Yellowstone National Park: Geological Society of America Abstracts with Programs 26(6):5.
Church, M. and M.J. Miles. 1987. Meteorological antecedents to debris flows in southwestern British Columbia; some case studies. In: J.E. Costa and G.F. Wieczorek (eds.). Debris flows/avalanches: Geological Society of America Reviews in Engineering Geology 7, p. 63-79.

Costa, J.E. 1988. Rheologic, geomorphic, and sedimentologic differentiation of water floods, hyperconcentrated flows, and debris flows. In: V.R. Baker, R.C. Kochel, and P.C. Patton (eds.). Flood geomorphology. John Wiley \& Sons, New York, p. 113121.

Despain, D.G. 1987. The two climates of Yellowstone National Park. Proceedings of the Montana Academy of Science 47:11-19.

Douglas, A.V. and C.W. Stockton. 1975. Longterm reconstruction of seasonal temperature and precipitation in the Yellowstone National Park region using dendroclimatic techniques. Report to the U.S. National Park Service-Yellowstone. Laboratory of Tree-Ring Research, University of Arizona, Tucson.

Ellen, S.D. and R.W. Fleming. 1987. Mobilization of debris flows from soil slips, San Francisco Bay region, California. In: J.E. Costa and G.F. Wieczorek (eds.). Debris flows/avalanches. Geological Society of America Reviews in Engineering Geology 7, p. 31-40.

Ely, L.L., Y. Enzel, V.R. Baker, and D.R. Cayan. 1993. A 5000-year record of extreme floods and climate change in the southwestern United States. Science 262:410-412.

Fritts, H.C. and X.M. Shao. 1995. Mapping climate using tree-rings from western North America. In: Climate Since A.D. 1500. R.S Bradley and P.D. Jones (Eds.). New York, Routledge. pp. 269-295.

Grove, J.M. 1988. The Little Ice Age. Methuen, New York. 
Hale, M.E. 1973. Growth. In: The Lichens. V. Ahmadjian and M.E. Hale (Eds.). Academic Press, New York. p. 473-492.

Hupp, C.R., W.R. Osterkamp, and J.L. Thornton. 1987. Dendrogeomorphic evidence and dating of recent debris flows on Mount Shasta, northern California. U.S. Geological Survey Professional Paper 1396-B.

Innes, J.L. 1983a. Use of an aggregated Rhizocarpon "species" in lichenometry; an evaluation. Boreas 12:183-190.

Innes, J.L 1983b. Lichenometric dating of debrisflow deposits in the Scottish Highlands. Earth Surface Processes and Landforms 8:579-588.

Innes, J.L. 1984. The optimal sample size in lichenometric studies. Arctic and Alpine Research 16:233-244.

Innes, J.L. 1985a. Lichenometry. Progress in Physical Geography 9:187-254.

Innes, J.L. 1985b. A standard Rhizocarpon nomenclature for lichenometry. Boreas 14:83-85.

Jahns, H.M. 1973. Anatomy, morphology and development. In: The Lichens. V. Ahmadjian and M.E. Hale, Eds. p. 3-58. Academic Press, New York.

Jones, P.D. and R.S. Bradley. 1995. Climatic variations over the last 500 years. In: R.S Bradley and P.D. Jones (Eds.). Climate since A.D. 1500. Routledge, New York. pp. 649-665.

Knox, J.C. 1993. Large increases in flood magnitude in response to modest changes in climate. Nature 361:430-432.

Meko, D.M. 1995. Dendroclimatic evidence from the Great Plains of the United States. In: R.S Bradley and P.D. Jones (Eds.). Climate since A.D. 1500. Routledge, New York. pp. 312-330.
Meyer, G.A., S.G. Wells, R.C. Balling, Jr., and A.J.T. Jull. 1992. Response of alluvial systems to fire and climate change in Yellowstone National Park. Nature 357:147-150.

Meyer, G.A., S.G. Wells, and A.J.T. Jull. 1995. Fire and alluvial chronology in Yellowstone National Park: Climatic and intrinsic controls on Holocene geomorphic processes. Geological Society of America Bulletin 107:1211-1230.

O'Hara, P.M. and G.A. Meyer. 1995. Morphometric analysis and flood potential of drainage basins in northeastern Yellowstone. In: G.A. Meyer (Ed.). Late Pleistocene-Holocene evolution of the northeastern Yellowstone landscape: Friends of the Pleistocene, Rocky Mountain Cell field trip guide, p. 23-25.

Pierce, K.L. 1974a. Surficial geologic map of the Abiathar Peak quadrangle and parts of adjacent quadrangles, Yellowstone National Park, Wyoming and Montana. U.S. Geological Survey Miscellaneous Geological Investigations Map I-646. scale $1: 62,500$.

Pierson, T.C., and J.E. Costa. 1987. A rheologic classification of subaerial sediment-water flows. In: J.E. Costa and G.F. Wieczorek (Eds.), Debris flows/avalanches. Geological Society of America Reviews in Engineering Geology 7, p. 1-12.

Simpson, E.D., and G.A. Meyer. 1995. Changes in flood magnitudes and processes in northeastern Yellowstone Park. Geological Society of America Abstracts with Programs 27(4):55.

Schumm, S.A. 1991. To interpret the Earth: Ten ways to be wrong. Cambridge University Press. 133 p.

Trewartha, G.T. 1981. The Earth's Problem Climates. Univ. of Wisconsin Press, Madison. 
Whitlock, C. and P.J. Bartlein. 1993. Spatial variations of Holocene climatic change in the Yellowstone region. Quaternary Research 39:231-238. 